\title{
OOME BUTTERFLIES AND SKIPPERS FROM THE MILK RIVER-LOST RIVER AREA OF SOUTHEASTERN ALBERTA
}

W. W. SMITH, 8200 Elbow Drive, Calgary, Alberta, and C. D. BIRD, Department of Biology, University of Calgary

Very few ecological investigations ave been conducted in the Milk iver and Lost River valleys of putheastern Alberta. In the summer 1974, intensive field work was arried out in this area, by Smith. eriodic checks were also made roughout the summers of 1975 and 976. During the course of this field ork, 29 species of butterflies and ippers were observed, with collecons made of most species. Included ere are the first published report of leidemeyer's Admiral (Limenitis eidemeyeri oberfoelli) for Canada, e first published report of Dun kipper (Euphyes vestris metacomet) $r$ Alberta, as well as reports of veral other species whose ocirrence in Alberta has been poorly ccumented. Also included are three pecies that were collected by other cople previous to 1974.

The area dealt with in this paper is me 270 square miles of grassland id valleys centered on the Milk ver in the Pinhorn Grazing Reserve, id the Lost River on the west edge of e Onefour Experimental Station. his arid area, corresponding to a lute Upper Sonoran zone, is ogeographically unique. Such inresting species as Yucca (Yucca auca), Northern Scorpion (Vejovis ireus), Short-horned Lizard hrynosoma douglassi), Yellowllied Marmot (Marmota flavivens), and Bullock's Oriole (Icterus Ibula bullockii) occur here. The minant feature of this region is the ntly undulating native grasslands. ese grasslands are of the mixed ass type with the major species beStipa spp. and Bouteloua gracilis. e two major valleys and their sociated coulees lend a great gree of diversity to the otherwise simplistic grasslands. Communities range from barren, actively eroding slopes, short-grass prairie hillsides, numerous shrub communities, to tree stands. Shrub communities of this area are highly variable and include Thorny Buffalo Berry (Shepherdia argentea), Wolf Willow (Elaeagnus commutata), Buckbrush (Symphoricarpos occidentalis), Rose (Rosa supp.), Sagebrush (Artemisia cana), Greasewood (Sarcobatus vermiculatus), Willow (Salix spp.), Juniper (Juniperus spp.), Saskatoon (Amelanchier alnifolia), and Chokecherry (Prunus virginiana). Shrub stands may be of a single species, or a heterogenous mixture of several to many species. Mixed shrub communities occurring in the upper reaches of small, damp coulees support the largest populations of butterflies.

Tree stands are of two main types. Pure, sometimes extensive, stands of Cottonwood (Populus sargentii) occur along the Milk River. Stands of hybrid poplars grow in thick, but usually small, clumps in the moister portions of some coulees.

The badland topography of the Milk River is similar to, but not as extensive as, the badlands occurring along the Red Deer River in the Drumheller-Dinosaur Park area. In many cases, the vegetation of the two areas is quite similar. Many species of butterflies that occur along the Milk River, also occur along the Red Deer River. ${ }^{7} \mathrm{~A}$ rather similar area is that of the former Nemiskam National Park, 40 miles to the northwest. ${ }^{5}$

Both the study area and that of the Red Deer River badlands are quite arid and receive the lowest amount of rainfall in Alberta. The mean annual 


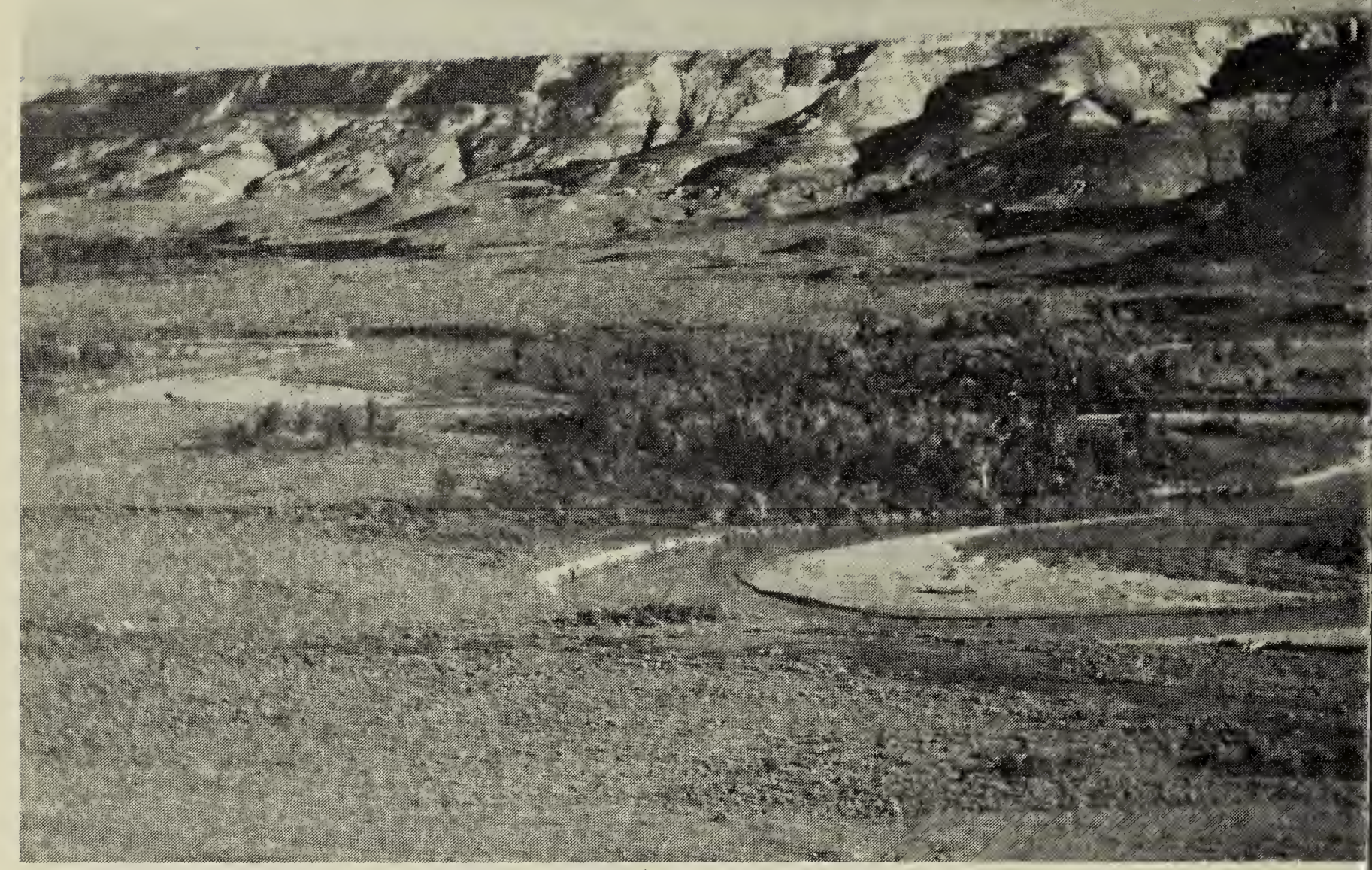

Fig. 1. Milk River, Alberta, showing Weidemeyer's Admiral habitat

W. W. Smit

precipitation at Onefour is 12.0 inches, the mean annual temperature is $40.3^{\circ} \mathrm{F}$, and the mean annual evaporation is 30.6 inches. Precipitation varies from year to year (7.62 inches to 18.06 inches) and the temperature has ranged from a low of $-51^{\circ} \mathrm{F}$ to a high of $+108^{\circ} \mathrm{F}$. The prevailing winds are north-westerly, with westerly chinooks occurring during the winter. High winds throughout the year are frequent. ${ }^{6}$

Intensive collecting of butterflies and skippers was done every two weeks from early June to early August in 1974. As a result, a few species that fly in early spring, and fall were undoubtedly missed. Collecting was done throughout the entire study area with a slight emphasis on coulee habitats.

The butterfly fauna of the Milk River-Lost River area may be influenced by the Sweetgrass Hills, of Montana, which are some 30 miles south-south-west of the study area. These hills could serve as a source of wind-blown strays; and may allow for colonization of similar pockets of habitat in the study area.

\section{SPECIES LIST}

The common and scientific nam employed are essentially those Hooper's "Butterflies of Saskatchewan' Dates listed after a species name refer the date specimens were collected, and/ observed.

DUN SKIPPER (Euphyes vestr metacomet). June 30, 1974. This is the fit published report from Alberta, althous specimens had been previously collecte in southern Alberta and are in a priva collection in Lethbridge. Hooper indicat that this species should occur widely Alberta. ${ }^{4}$ The specimen collected was in coulee bottom containing greasewor and sagebrush.

DELAWARE SKIPPER (Artylone delawa lagus). July 3,1974 ; July 24,1975 . Found shrubby areas of coulee bottoms.

\section{COMMON CHECKERED SKIPPE} (Pyrgus communis communis). June June 10,1974. Found in sagebrush flats a grassy areas of coulee bottoms.

PERSIUS DUSKY WING (Erynnis pers) fredericki). August 3, August 7, 19: Found in low shrub areas in coulees.

SILVER-SPOTTED SKIPPER (Epargyre clarus clarus). July 3, July 10, 1974. Found tall shrub areas in coulees. 
PRESS HILLS OLD WORLD VALLOWTAIL (Papilio machaon dodi). he 11, 1974. Found in mixed grassland d willows along the edge of cotiwoods.

IUCE'S SWALLOWTAIL (Papilio bairdii 1cei). July 24, 1975. Found in mixed ssland near coulee edges.

NADIAN TIGER SWALLOWTAIL pilio glaucus canadensis). Only ocionally observed in treed side coulees.

BBAGE WhITE (Pieris rapae). Comin in most habitats.

FALFA BUTTERFY (Colias ytheme). Common in most habitats.

AY HAIRSTREAK (Strymon melinus muli). August 7, 1974. Found in coulee ttoms containing sagebrush and asewood.

RPLISH COPPER (Lycaena helloides). ie 29, 1975. Found in rose and sagebrush mps on the edge of an oxbow lake.

LISSA BLUE (Lycaeides melissa lissa). June 30, July 3, July 5, August 3, gust 7,1974 ; June 29, June 30 , July 24 , 5 . Found commonly in many habitats.

EENISH BLUE (Plebejus saepiolus ica). June 6 , June 7 , June 8 , June 10 , 4 ; June 29, 1975. Found in low shrub as throughout.

OTTED BLUE (Philotes enoptes ana). June 30, 1974; June 30, 1975. cimens were found in short-grass and ubby areas in coulee badlands. viously known from Alberta only from Cypress Hills, with its main range ther south in the United States. ${ }^{4}$
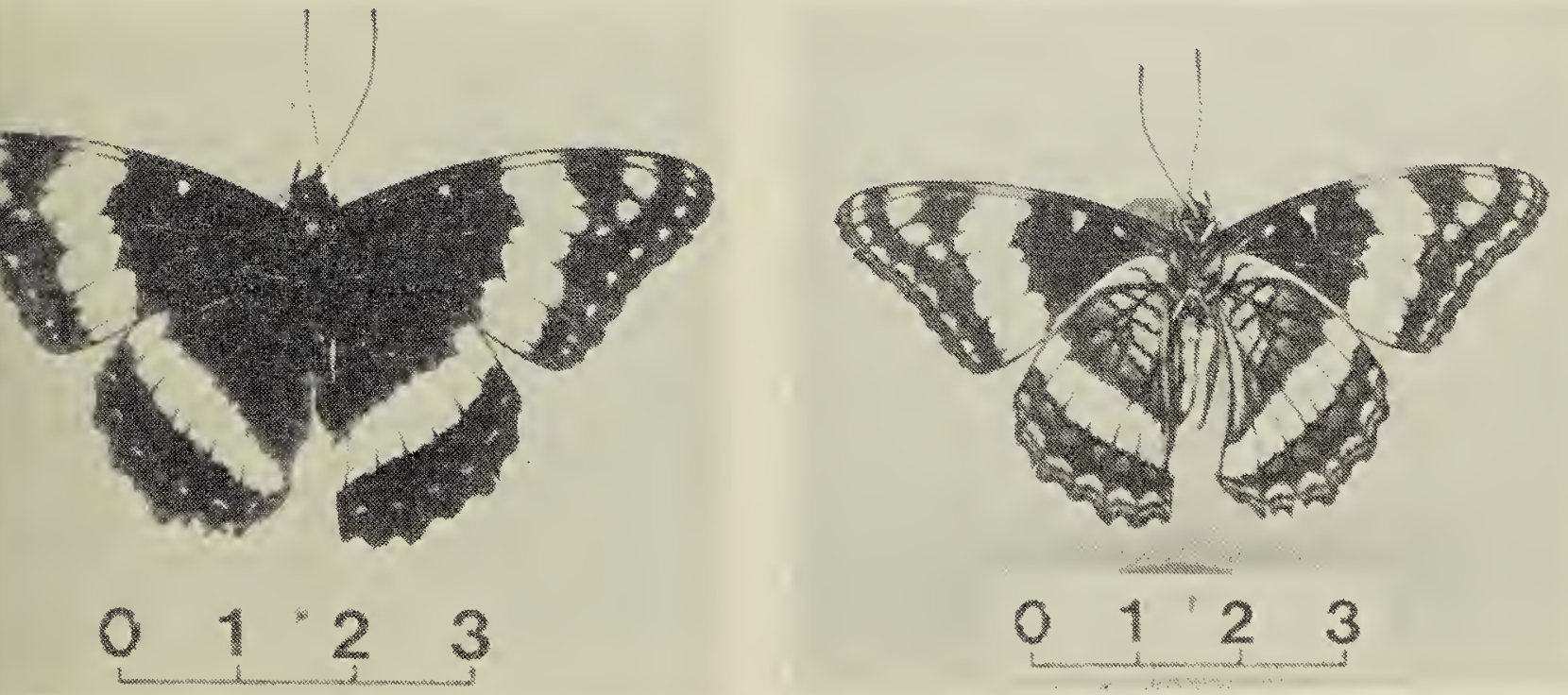

W. W. Smith

2. Weidemeyer's Admiral (Limenitis weidemeyeri oberfoelli) collected in the Milk r-Lost River area, Alberta on July 3, 1974 by W. W. Smith. The scale is in centimeters 
were observed in early July 1976 along creekside shrub habitats.

RED ADMIRAL (Vanessa atalanta). Observed in cottonwood stands.

MOURNING CLOAK (Nymphalis antiopa). Observed in tall shrub and poplar stands.

PEARL CRESCENT (Phyciodes tharos pulchella). June 7 , June 10, 1974; June 29, 1975. Found in low shrub areas.

CARLOTA CHECKERSPOT (Chlosyne gorgone carlota). June 10, 1974. Found in low shrub and grassy areas.

ACASTA CHECKERSPOT (Chlosyne acastus acastus). June 30, July 5, 1974; June 30,1975 . Found in coulee bottoms containing sagebrush, greasewood and grasses. This species is previously known in Alberta only from badland areas along the Red Deer and Oldman River systems.

EDWARD'S FRITILLARY (Speyeria edwardsii). July 21, 1967. Collected by A. G. Edmund.

CALLIPPE FRITILLARY (Speyeria callippe calgariana). July 1 , July 3 , July 5 , 1974; July 24, 1975 . Found in mixed prairie areas.

APHRODITE (Speyeria aphrodite mayae). July 24, 1975. Found in long grass and shrub areas.

RINGLET (Coenonympha inornata benjamini). June 7,1974 ; June 29, 1975. Found in grassland areas.

COMMON WOOD NYMPH (Cercyonis pegala ino). July 6, August 3, 1974; July 24, 1975. Found in most grass and shrub areas.
SMALL WOOD NYMPH (Cercyonis oe charon). June 30 , July 8,1974 ; July 24,19 Found in areas of sagebrush a greasewood.

RIDING'S SATYR (Neominois riding ridingsii). July 3, 1973. Collected by Hilchie.

VARUNA ARCTIC (Oeneis uhleri varun June 7 , June 10, June 11, 1974. Found mixed grassland areas.

'BIRD, C. D. and N. KONDLA. 1974. Sor skippers and butterflies from Dinosa Provincial Park, Alberta. Blue Jay $87-88$.

2BROWN, F. M. 1960. A badlands sL species of Limenitis weidemey Edwards (Lepidoptera, Nymphalida American Museum Novitates, Numb 2018, 6 pp.

${ }^{3}$ GREGORY, W. W. 1975. Check-list of $t$ butterflies and skippers of Cana Lyman Entomological Museum a Research Laboratory Memoir No. 1975.

${ }^{4}$ HOOPER, R. 1974. Butterflies of Sask chewan. Saskatchewan Department Renewable Resources.

${ }^{5}$ SOPER, J. D. 1949. Notes on the fau of the former Nemiskam National $P$ and vicinity, Alberta. Canadian Fi Naturalist 63: 167-182.

${ }^{6}$ THOMAS, M. K. 1953. Climatologi atlas of Canada. Canada Department Transport. Ottawa 255 pp.

\section{A SNAKE'S WINTER}

\section{ALEXANDER W. L. HAWLEY*}

Any animal that lives year-round in the Prairie Provinces must tolerate long and cold winters. Different animals cope with these severe conditions in different ways. Many homeotherms (warm-blooded animals) are capable of staying active throughout the winter if food remains available. Maintenance of a high metabolic rate and good insulation

*Condensed from Manitoba Nature, Vol. 14, No. 3, Autumn, 1973. (i.e., hair, feathers, and subdermal $f$ permit maintaining a bo temperature high enough to allow tivity. Some homeotherms becor torpid during the winter, occasiona becoming active to feed on stor food. Others, particularly tho whose food source essentially $c$ appears for the winter, cannot me the high energy demands of stayi active under such cold conditions a are forced to hibernate.

Since their body temperature 